\title{
Discussion
}

\section{Is STS Truly Revolutionary or Merely Revolting?}

\author{
Steve Fuller
}

\begin{abstract}
The distinctive research character of science and technology studies - its post-social, object-centred, anti-normative perspective - is presented as an ideological expression of the client-driven nature of knowledge production in these neo-liberal times. This accounts for both STS's increasing utility and lack of overarching research programme.
\end{abstract}

Key words: social epistemology, neo-liberalism, science and technology studies.

By certain obvious standards, Science \& Technology Studies (STS) has made progress over the past quarter century. STS is now clearly defined by a cluster of well-established journals, whose articles are increasingly recognised outside the field's borders. (By one count, Bruno Latour is the fifth most highly cited social scientist overall.) If STS departments have not spread as much as one might wish, their graduates have nonetheless succeeded both in and out of academia. Moreover, for policymakers virtually everywhere, STS is seen as a uniquely desirable competence for coming to grips with technoscience in contemporary society. In retrospect, the 'Science Wars' that closed the 1990s, while uncomfortable for a few of us, has managed - however unwittingly - to impress upon the general public the need to re-nego- tiate the social contract of science and technology that went unquestioned during the Cold War. All good news for STS, it would seem.

However, in one respect STS has not really proved itself: Are we a force for good in the world? Recall a slogan from the 1960s: "If you're not part of the solution, you're part of the problem." (I can already hear the objections: "How asymmetrical! How beholden to dichotomous thinking!" But please bear with me while I excavate this ancient discourse.) Back then, all self-proclaimed progressive thinkers were touched by the hand of Marx. There was a clear sense of where all of 'us' were supposed to be heading. Of course, Liberals, Social Democrats and Communists differed over the means, the speed, and the distribution of the burden to complete the task at hand. But 
the ultimate goal was largely the same: A society where everyone could fulfil their potential without inhibiting the ability of others to do the same - and importantly, where everyone recognised the desirability of this goal. STS began to acquire an institutional presence as this consensus started to be questioned - and really gained momentum once the consensus was blown apart in the 1980s.

Socialism's setbacks - ranging from the fiscal crisis of the welfare state to the collapse of the Soviet Empire-led to not only a profound questioning of political allegiances, but more importantly a profound questioning of politics altogether. Along with scepticism about the meaningfulness of "left" versus "right" came a withdrawal of the younger generation that is, those who have come of age since around 1980 - from the party politics and electoral processes that had underwritten the left-right polarity for two centuries. Perhaps the subtlest manifestation of this shift has been the semantic dissipation of political language: Nowadays just about everything is "political" except the practices conventionally associated with politics. Thus, the incorporation of non-human agents into academic and popular narratives is "political," as are the attempts by various well-organized interest groups to have their lifestyles recognised and secured. The hand of STS in these developments is, of course, unmistakable.

What STS has helped politics to losea sense of res publica or the "common weal" - is matched by its complicity with the "knowledge society" discourse that purports to say that knowledge is produced just about everywhere except universities, which are now reduced to 'trading zones' (Nowotny etal. 2000). Notwith- standing Latour's (1993) obfuscations about the 'a-modern' and the 'non-modern', the programme he assembled at the 2004 meeting of the Society for Social Studies of Science in Paris clearly fulfilled Lyotard's (1979) prophecy of an increasingly dispersed knowledge society. Gone is the idea of knowledge that may be made universally available from a central academic location. Moreover, there are no reflexive surprises here. STS practitioners do not merely represent, perform or 'give voice' to groups traditionally excluded by democratic politics. They themselves are often academically marginal - the contract-based teachers and researchers that Daryl Chubin once dubbed the 'unfaculty'. But even the more successful members of the field continue to harbour resentment to traditional academic structures and cynicism to 'politics as usual'. As idea or institution, politics and academia are portrayed as parasitic and peremptory over the full range of what is increasingly given such generic but no less metaphysically freighted names as "agency" or "life." It would not surprise me if before long the word 'knowledge' is dropped from the STS vocabulary for ranging too prescriptively over the available resources to get action.

My guess is that future historians will find four things behind this perspectival shift, which I present in order of increasing generality:

1 . The resentment of the younger generation toward older politicians and professors who have abused the offices to which the young themselves may have once aspired. This is most clearly manifested in scepticism toward the institution of life-long academic tenure, which was designed to encourage the pursuit of inquiry with impunity, but 
has too often instead led to lack of public accountability and intellectual stagnation.

2. An intolerance for the level of error that invariably arises from purportedly 'free' action and inquiry. After all, permitting politicians and academics a free hand in their dealings has just as often led to outright disasters as mere stagnation or squandered opportunities. Thus, the pendulum swings back, resulting in a collapse of the temporal distinction between a policy proposal and its subsequent correction (or reversal) into an undifferentiated state of 'ambivalence', whereby if you don't already know in advance that good will be produced, you are hesitant to try at all. This line of thinking lay behind the 'precautionary principle' and, more generally, the 'risk society' - both of which have received strong support from STS.

3. Such impatience with learning from mistakes reflects an intellectual captivity to the accelerated pace of life - or 'addiction to speed', as Paul Virilio would say. It tends to conflate diminishing returns on investment with the outright conversion of benefits to harms. For example, the fact that women have not made as much social progress in the last decade as they did in the next-to-last decade is taken to mean that the original strategy had been based on a faulty 'totalising' conception of gender, when it may simply point to the need for greater tactical sophistication at a practical level to achieve the ultimate goal. One can agree with Wittgenstein that the meaning of a word like 'gender' does not dictate its full usage without concluding that the word is useless. Yet, the ease with which STS relinquishes 'universalist' ambitions in this fashion is symptomatic of a loss of trans-generational memory that forgets how much worse things were not so long ago. Such collective amnesia is only abetted by STS's studied anti-institutionalism.

4. Last but not least is the ongoing psychic need to make the most of the hand that fate has dealt, which leads each new generation to find silver linings in even the darkest clouds. Jon Elster coined the useful phrase 'sweet lemons' (the converse of 'sour grapes') for this phenomenon. Once one loses faith in the traditional academic and political structures, the Wittgensteinian aim of 'leaving the world alone' starts to look less bad than any more activist alternative. In this context, 'radicalism' amounts to little more than allowing what had been previously hidden to reveal itself. This manner of speaking, reminiscent of Heidegger's conception of truth as aletheia, effectively divests the analyst of any responsibility for what is revealed, since, as Latour says, the STS practitioner is merely 'following the actants'.

To be sure, this passive yet receptive stance enables STS to exert a tactical advantage over rival empirical analysts, notably Marxists, whose conceptual framework is so normatively loaded that it cannot register certain facts without passing judgement on them. From an STS standpoint, this results in wildly unreliable observations that tend to over- or under-value phenomena, depending on whether they are deemed 'emancipatory' or 'exploitative', 'progressive' or 'reactionary' - or even whether the object of inquiry is identified as a 'producer' or a 'consumer'. Whereas the client of Marxist analysis is likely to come away feeling guilty for her complicity in the situation that led to the employment of the Marxist's services in the first place, the STS client simply feels epistemically enhanced and welcomes another opportunity to learn more in the future. However, the history of client-driven ethnog- 
raphy has shown that the client's enlightenment typically comes at the expense of the power that the object of inquiry had exerted through its obscurity. Depending on the original balance of power between client and object, this may or may not be a desirable outcome. STS practitioners do not care to decide the matter because they never know who might require their services in the future.

A consequence of STS's professionalised value neutrality is a profoundly distorted understanding of the equation 'Knowledge is power'. In its original Enlightenment form, the equation was meant to express that the more we know, the less power others have over us. Indirectly, of course, this implies that our own power grows - but only in the strict sense of the original Latin potentia, that is, the sphere of possible action grows. In this somewhat metaphysical sense more knowledge makes us 'more free', but that entails new burdens as suddenly we are faced with a larger decision space than we had previously envisaged. It is worth recalling that the opposing model was one of religious leaders who ruled by promulgating dogmas that discouraged people from trying to move in new directions. These leaders were able to get their way not because they could enforce their will in all cases but because, in most cases, the rest of society already believed that nothing could be done to oppose them and hence nothing was tried.

I fear that STS has lost sight of this context. Specifically, 'Knowledge is power' was meant to loosen, not tighten, the relationship between knowledge and power, especially in its ordinary sense of 'the capacity to get action'. In contrast, much of the attraction of STS research to both academics and policymakers comes from revealing intermediaries whose distinctive knowledge enables them to act in ways that have perverse effects on the schemes promoted by nominally more powerful agents. The implicit explanation for this phenomenon is that the intermediaries live radically different lives from the would-be hegemons. From this STS infers that power resides in one's specific epistemic embodiment. However, from an Enlightenment standpoint, a social epistemology based on such an 'indigenised' conception of knowledge is simply a recipe for democratising rule by high priests that is, many more priests ruling over much smaller domains.

STS's all too open normative horizons of inquiry would have been criticized in the past for its 'mere instrumentality', 'rank opportunism' and 'lack of clear theoretical focus'. However, nowadays it is given a philosophical high gloss with the help of some funky process metaphysics inspired by two outliers in $20^{\text {th }}$ century philosophy, Henri Bergson and Alfred North Whitehead (Latour,2004). A sociologist of STS knowledge - a social epistemologist - would relate this shift in status to the lack of institutional protection for the vast majority of STS practitioners today. That academics could enforce their will on the rest of society may have been always an illusion, but at least they used to exert sufficient control over their own sphere of activity to launch a consistent critique. But what happens once the prospect of a stable counterpoint vanishes?- Process metaphysics, whatever its other merits, is the ideological expression of researchers in perpetual need of shoring up their optimism as they remain in profound ignorance about the source of their next 
paycheque. In that context, whatever appears on the horizon is easily interpreted as a harbinger of good things - at least until the next phase in the process emerges.

That STS practitioners nowadays root around in the metaphysical marshlands of Bergson and Whitehead to persuade themselves of these semantic manoeuvres suggests a deep state of denial about how our field might be judged. After all, the quickest theoretical route to most of the 'radical' things STS wants to say these days about the 'distributed' and 'emergent' nature of technoscience is through the work of Friedrich von Hayek, who provided a systematic metaphysical underpinning to the market that would have made even Adam Smith blush. Of course, Hayek wore his politics - or I should say his anti-politics (he was one of the modern sceptics about the value of elections) - very much on his sleeve. This explains Hayek's influence on the likes of Reagan, Thatcher and Pinochet. It equally explains why our ever politically correct field has been reluctant to embrace Hayek. After all, we self-avowed 'radical' thinkers in STS would hate to think that we have always already been neo-liberal. But future historians may judge otherwise - and more harshly. We may turn out to have been part of 'the problem' rather than 'the solution' that institutions like the university and movements like socialism - however inadequately - tried to address. In any case, future historians will find STS's tragically hip turns of thought an endless source of insight about the overall mindset of our times.

So, if the question is not too grandiose, what has been STS's contribution to world civilization? At the start of my ca- reer, in the early 1980s, I would have said that STS contributes to the second moment of a dialectic that aims to realize the Enlightenment dream of truly universal knowledge. I read works like Bloor (1976) and Latour \& Woolgar (1979) as revealing the captivity of normative philosophy of science to wishful thinking about the history and sociology of science. Philosophers wrote as if scientists were trying to live up to their normative ideals, even though the philosophers themselves could not agree on what those ideals were. STS showed that philosophers suffered less from bad faith than sheer credulousness. They - and such sociological fellow-travellers as Robert Merton - made the fatal mistake of believing their own hype. Like overzealous imperialists, philosophers failed to recognize the 'made for export' quality of their own normative discourse. Put crudely, the 'scientific method' had more impact in disciplining school children and regimenting the non-sciences than in regulating the practices of real scientists.

My own project of 'social epistemology' has been dedicated to bridging this very significant gap between the 'is' and the 'ought' (Fuller, 2002a). It has increasingly led me to consider the conditions under which knowledge is institutionalised as a public good - that is, an entity capable of benefiting the vast majority not involved in its production. In the current STS Newspeak, this idea is unthinkable since all knowledge is necessarily 'co-produced'. Thus, the sorts of problems economists have traditionally associated with public goods, such as the 'tragedy of the commons', can be dismissed as simply efforts to demean the ingenuity of our successors to interpret 
the potential of the commons rather differently from us. Undeterred by such sophisms, I have been led to champion both the classical university and more new-fangled consensus conferences, while opposing the excesses of 'evidence-based policy' and 'knowledge management', to name two fields that capitalise on the rhetoric of 'access', 'inclusion' and even 'democratisation' only to deskill inquirers and debase organized inquiry (Fuller, 2000, Fuller, 2002b). That STS practitioners have been all too eager to contribute to these fields may be indicative of just how much the field has fallen victim to its own success. We have had much to say about deconstruction, but precious little by way of reconstruction.

If nothing else, STS has proven 'useful' to a wide range of constituencies. These include science policymakers trying to foster basic research, social engineers interested in maximising the diffusion of a new technology and, of course, line managers in search of creative accounting techniques to cut costs and boost profits. That STS has afforded so many applications, despite its equally many theoretical controversies, demonstrates just how eminently detachable our field's practices are from its theories. A Marxist devoid of charity might even suggest that the more exotic theories by Latour and Donna Haraway, to which the entire field of STS tends to be reduced by its many admirers in cultural studies, are little more than 'ideological superstructure' on the soft-focus surveillance that characterises so much of STS empirical work. Having now evaluated scores of grant proposals, academic manuscripts, doctoral dissertations and candidates for tenure and promotion in several countries, I must confess some sympathy with our Marxist's jaundiced judgement. There is probably no other field whose members are so adaptable to circumstance. STS is a veritable cockroach in today's intellectual ecology - the ultimate compliment, some evolutionists might say.

STS offers something for everyone something funky for the high theorists blissfully ignorant of the workings of technoscience and something more nuts-and-bolts for harried decisionmakers pressed to justify hard choices. What STS lacks is a unity of purpose, a clear sense of how its empirical work is, indeed, an application - or, still better, a test - of its theories. My concern with this absence of unity may strike you as a regrettable modernist hang-up. Nevertheless, it may also help to explain why academic institutionalisation has continued to elude STS. Moreover, in this respect, STS would not be unique. Devotees of the popular science literature read much of 'chaos' and 'complexity', which refer to certain mathematical properties of natural and artificial systems that have become easier to detect and represent in recent years because of technical advances in computer simulation. Many quite unrelated phenomena can be modelled now as chaotic and complex systems. But do they add up to a coherent world-view? Contrary to the extravagances of science popularisation, they don't. Chaos and complexity remain no more than a subset of the forms of quantitative analysis available for the conduct of normal science in a variety of disciplines. Something similar may be said about STS vis-à-vis the larger knowledge system.

Just like chaos and complexity, the 
leading so-called 'theory' in STS, actornetwork theory, is not really a theory at all but an all-purpose method (Law, 2004). Daniel Dennett, aping William James, has dubbed Darwin's theory of natural selection the 'universal solvent'. Actor-network theory works its methodological magic in just this way: You think you can isolate who or what is responsible for the larger effects in our technoscientific world?-Well, that must mean you haven't accounted for all the 'actors'. Once you've done this, you'll realize that 'agency' is distributed across a wide range of entities that transgress the usual ontological categories, not least human/non-human. After all, agency is no more than the capacity to act. When you take this point seriously, you'll resist the urge to jump to conclusions about the ascription of either 'blame' or 'credit'. Such moral qualities need to be spread more evenly, and hence more thinly, across a wider range of entities. Make no mistake: This is not anthropomorphism. It is almost the exact opposite. Actornetwork theorists aren't trying to attribute properties to, say, scallops and doorstops that were previously restricted to humans. Rather, they want to convert what these entities normally do into the benchmark of agency. The unspoken implication is that what remains distinctive to humans is valued less. Indeed, the unique displays of intelligence that have enabled us to dominate nature may be profligate - the metaphysical equivalent of industrial pollution in some fanciful 'political ecology', the field which Latour (2004) nowadays thinks he represents.

To be sure, STS did not originate this line of thought. But because the field travels with such light theoretical bag- gage, it is better placed than most to capitalise on it. Observed from this moment in intellectual history, STS is turning out to be the crucible in which the two great anti-humanist trends of the late $20^{\text {th }}$ century are being brought together in a heady stew with potentially explosive scientific and political consequences: The first is, broadly speaking, post-structuralist thought, rooted in Nietzsche and Heidegger and brought to fruition in '60s France in works by Roland Barthes and Michel Foucault that announced the death of something variously called 'the author', 'the subject' or simply 'man'. The second stream of anti-humanism stems from the technologically enhanced version of Neo-Darwinism that has come to dominate science policy and the public understanding of science in the post-Cold War era. Together they call into question the uniqueness of humanity, not least by displacing, if not actually disparaging, the two modern projects that have stood most clearly for that concept: social science and socialism (Fuller, 2005). Are we sure we want STS to be remembered as such a strong supporting player in this trajectory?

A sign of the times is that the literary agent John Brockman, one of the most important figures in the intellectual world today, has appropriated 'the third culture' - an old phrase for the social sciences - to cover an interdisciplinary broad church devoted to recovering the 'nature' in 'human nature'. Richard Dawkins, E.O. Wilson and Steven Pinker are just some of the names associated with Brockman's project, conveniently located at the website, www.edge.org, not to mention the many popular books he has helped to publish over the past 
quarter century, starting with the original cyborg anthropologist, Gregory Bateson. STS's own 'made for export' gurus, Bruno Latour and Donna Haraway, are unacknowledged affiliates. Latour has never hid his belief that a preference for 'biosociality' over 'sociobiology' is ultimately a matter of political correctness among English speakers. He is happy to live with either or both. As for Haraway, she has literally gone to the dogs in her latest tract, A Companion Species Manifesto (Haraway, 2003). Wading through her endless namechecks and abuses of the subjunctive mood, one gets the impression that Haraway really does believe that the best way to understand the human condition is by studying our relations with canines. This might work for humans who have already exhausted the more obvious modes of inquiry or Martians in search of the exact distinction between humans and dogs. But we don't live in either world. It is one thing for STS to be inspired by science fiction, quite another to become science fiction.

We are entering an era that may be remembered for its casualisation of the human condition. Technological advances are making it easier for people to come in and out of existence, to which STS makes its own conceptual contribution by manufacturing a discourse that facilitates the exchange between human and non-human qualities. Add to this the emergence of Peter Singer as the world's leading public philosopher, who now calls for a politics of the left that replaces Marx with Darwin as its standardbearer. Singer (1999) sees it in terms of an expansion of the moral circle to cover all forms of life. His utopian vision presupposes that we have already closed the moral circle around all forms of human life. Yet, the growing disparity between the rich and the poor - both between and within countries - testifies otherwise. Many in STS are attracted by utopian politics, pretending that we are much farther along in history than we really are. At least, Singer displays the courage of his convictions by providing arguments for why humans should make room for non-humans by limiting and even forgoing their own lives. STS certainly knows how to talk the talk. But does it dare walk the walk?

\section{Note}

This article is a revised and expanded version of the 2005 annual Nicholas Mullins Memorial Lecture in Science \& Technology Studies at Virginia Tech.

\section{References}

Bloor, D.

1976 Knowledge and Social Imagery. London: Routledge.

Fuller, S.

2000 The Governance of Science. Milton Keynes: Open University Press.

2002a Social Epistemology. $2^{\text {nd }}$ edn. (Orig. 1988). Bloomington: Indiana University Press.

2002b Knowledge Management Foundations. Woburn: Butterworth-Heinemann.

2005 Re-Imagining Sociology. London: Sage. Haraway, D.

2003 The Companion Species Manifesto. Chicago: Prickly Paradigm Press.

Latour, B.

1993 We Have Never Been Modern. Cambridge: Harvard University Press.

2004 The Politics of Nature. Cambridge: Harvard University Press. 
Latour, B. \&Woolgar, S.

1979 Laboratory Life. London: Sage.

Law, J.

2004 After Method. London: Routledge.

Lyotard, J.-F.

1983 The Postmodern Condition. Minneapolis: University of Minnesota Press.

Nowotny, H., Scott, P. \& Gibbons, M.

2000 Re-Thinking Science - Knowledge and the Public in an Age of Uncertainty.

Singer, $\mathrm{P}$.

Cambridge: Polity Press.

1999 A Darwinian Left. London: Nicholson \&Weidenfeld.

Steve Fuller

University of Warwick, U.K.

s.w.fuller@warwick.ac.uk 